\title{
Are intravaginal practices associated with human papillomavirus and the development of cervical cancer? A systematic literature review
}

\author{
Tafadziswa T Museba $^{1}$ ㅇ, Rebecca J Howett ${ }^{2} \mathbb{C}$, Christine Campbell $^{1}$ \\ 1 Usher Institute, University of Edinburgh, Teviot Place, Edinburgh, United Kingdom, ${ }^{2}$ NHS Education for Scotland, West Port, Edinburgh, United \\ Kingdom \\ Keywords: intravaginal practices, human papillomavirus, cervical cancer, human immunodeficiency virus
}

https://doi.org/10.29392/001c.21349

Journal of Global Health Reports

Vol. 5, 2021

\begin{abstract}
Background
Intravaginal practices (IVPs) are behaviours undertaken by women in diverse global settings for the promotion of hygiene and sexual health. Although evidence is inconclusive, it has been suggested that they may be harmful and associated with adverse gynaecological outcomes. The objective of this study was to investigate whether there is an association between IVPs, human papillomavirus (HPV) infection and the development of cervical cancer. As human immunodeficiency virus (HIV) infection may be a factor accelerating progression, recent evidence on the association between IVPs and HIV was also considered.
\end{abstract}

\section{Methods}

A systematic review of primary observational studies was carried out according to PRISMA (Preferred Reporting Items for Systematic Reviews) guidelines. A detailed search strategy was developed and modified for use in six databases and grey literature sources, searching from 01 January 1990 to 03 June 2019. Due to marked heterogeneity, narrative synthesis was used to combine findings.

\section{Results}

Twenty studies met the review criteria. The majority of studies were cross-sectional, and of moderate to low quality. A total of 14,493 participants were included, from 15 countries. IVP prevalence ranged from below $10 \%$ to over $90 \%$ across study populations. Six of eleven studies found an increased risk of HPV infection with IVPs; five of seven studies found an increased risk of cervical disease with IVPs. Two studies examining association of IVPs with risk of HIV infection were identified: both found associations with intravaginal cleansing, one found an association with intravaginal insertion. Potential moderator variables including the types of substances used, the frequency, timing and duration of IVP use were assessed: evidence was conflicting and inconsistent.

\section{Conclusions}

Current evidence is largely suggestive of a harmful association between IVPs and the development of cervical cancer. However, significant methodological limitations were recognised; there is a need for well-designed studies using consistent definitions and classifications.

Intravaginal practices (IVPs) are behaviours undertaken by women for the promotion of hygiene and sexual health in sub-Saharan Africa, South-East Asia, and North and South America. A classification of different IVPs has been proposed by the World Health Organization (WHO) Gender, Sexuality and Vaginal Practices (GSVP) Study Group ${ }^{1,2}$ (Box 1). Use of IVPs can alter the vaginal micro-environment, and are postulated to lead to several adverse gynaecological outcomes. ${ }^{3-5}$ This has been hypothesised to be due to micro-trauma, inflammation and changes to the vaginal $\mathrm{pH}$ and vaginal flora thereby interfering with protective immunological mechanisms. ${ }^{6-8}$ However, evidence to support this association has been conflicting. Most recently, the association of IVPs with human immunodeficiency virus (HIV) was investigated in two systematic reviews ${ }^{4,9}$ and was found to be inconclusive but potentially related to harm. No previous systematic review has assessed the general association of IVPs with human papillomavirus (HPV) and the development of cervical cancer.

Cervical cancer is a major cause of morbidity and mortal- 
ity in women worldwide, particularly in sub-Saharan Africa and Central and South America. ${ }^{10} \mathrm{HPV}$ infection as the necessary cause of cervical cancer, follows a well-understood pathway to progression, through infection and persistence of high-risk subtypes, to pre-cancerous changes and subsequent invasive cervical cancer. ${ }^{11}$ The initiation of HPV infection is thought to be facilitated by micro-trauma in the cervical epithelium. ${ }^{12}$ Some factors have been associated with an elevated cervical cancer risk in women with HPVinfection, such as long-term oral contraceptive use, smoking and other sexually transmitted infection (STI) co-infection. ${ }^{13}$ Additionally, HIV is recognised as a significant contributor to cervical cancer progression due to immunosuppression. ${ }^{14,15}$ As IVPs are often described in regions with high prevalence of HIV, HPV infection and cervical cancer, it is critical to continue to ascertain the possibility of risk associated with use of IVPs and HIV infection. These potential associations are illustrated (Figure 1).

\section{Box 1. Classification of Intravaginal Practices.}

The WHO Gender, Sexuality and Vaginal Practices (GSVP) Study Group ${ }^{1}$ proposed a classification for vaginal practices, of which only those that potentially have an effect on the vaginal mucosa have been described below:

- Intravaginal cleansing: Cleaning inside the vagina to remove excess fluid, which can include wiping or washing the genitalia internally using fingers or materials such as cotton wool or cloths. Douching, in which water or another solution is pumped into the vagina under pressure is also included in this.

- Intravaginal insertion: Placement of external products into the vagina, independent of $\mathrm{du}^{-}$ ration.

- Oral ingestion of substances that are believed to have an effect on the vagina.

- Vaginal steaming or smoking: Involves sitting over a heat source with steam created by oils, herbs and water.

- Anatomical modifications (self-administered): Introitus incision with herbs or traditional medicines inserted into the lesion. ${ }^{2}$

Other external practices such as external washing and external application have been excluded.

We describe a systematic review to assess the evidence of an association of IVPs with HPV infection, and the development of cervical cancer, using 'cervical disease' as an overarching term to encompass pre-cancerous changes and cervical cancer.

\section{OBJECTIVES}

In order to examine whether intravaginal practices are as- sociated with HPV infection and cervical cancer development, we systematically reviewed primary observational studies covering a range of IVPs in different geographical regions and their associations with HPV infection and cervical disease. Additionally, we examined recent evidence describing any association of IVPs with HIV infection.

\section{METHODS}

\section{PROTOCOL AND REGISTRATION}

A protocol was developed using the Preferred Reporting Items for Systematic Review and Meta-Analysis-Protocol (PRISMA-P) guidelines ${ }^{16}$ and is provided in Online Supplementary Document.

\section{ELIGIBILITY CRITERIA}

Studies eligible for inclusion were cohort, case-control and cross-sectional studies, investigating the relationship between intravaginal practices in women of all ages in any global setting and cervical HPV, cervical disease or HIV infection. A broad definition of IVPs was adopted, taking the practices as defined by the individual study authors but excluding practices that were only external or were not selfadministered. Where IVPs were examined as part of a risk factor profile, studies were eligible provided IVPs were analysed separately with effect measures given. No restrictions were placed on the purpose for conducting IVPs. Any studies that considered sexually transmitted infections in general without the specific mention of HPV or HIV infections were excluded. No location or language were specified to ensure the range of geographical variation was captured. In relation to date of publication, only studies published after 1990 were considered for HPV and only after 2008 for HIV due to the prior systematic reviews on the topic including studies published prior to this date. Both published and unpublished studies were eligible for inclusion.

\section{LITERATURE SEARCHES}

A comprehensive search strategy, devised with the help of a University of Edinburgh health sciences librarian, was adapted for use in six electronic databases, namely MEDLINE (Ovid Interface), EMBASE (Ovid Interface), Global Health (Ovid Interface), Cumulative Index to Nursing and Allied Health Literature (CINAHL, EBSCOhost), POPLINE (Population Information Online) and Web of Science, from 01 January 1990 to the 03 June 2019. Additionally, grey literature sources including OpenGrey, the Grey Literature Report, the WHO African Region Library and ProQuest Dissertations and Theses were searched and the reference lists of all full-texts for inclusion were scanned to identify any other relevant studies. Briefly, search terms were a combination of Medical Subject Headings (MeSH) and free text terms based on variations of the exposure and outcome of interest; namely 'intravaginal practice', 'vaginal douching', 'intravaginal insertion', 'intravaginal cleansing, 'hygiene', 'application', 'modification', 'dry sex', 'human papillomavirus', 'cervical dysplasia', 'human immunodeficiency virus' and 'sexually transmitted infection'. The detailed search strategy is available in Online Supplementary Doc- 


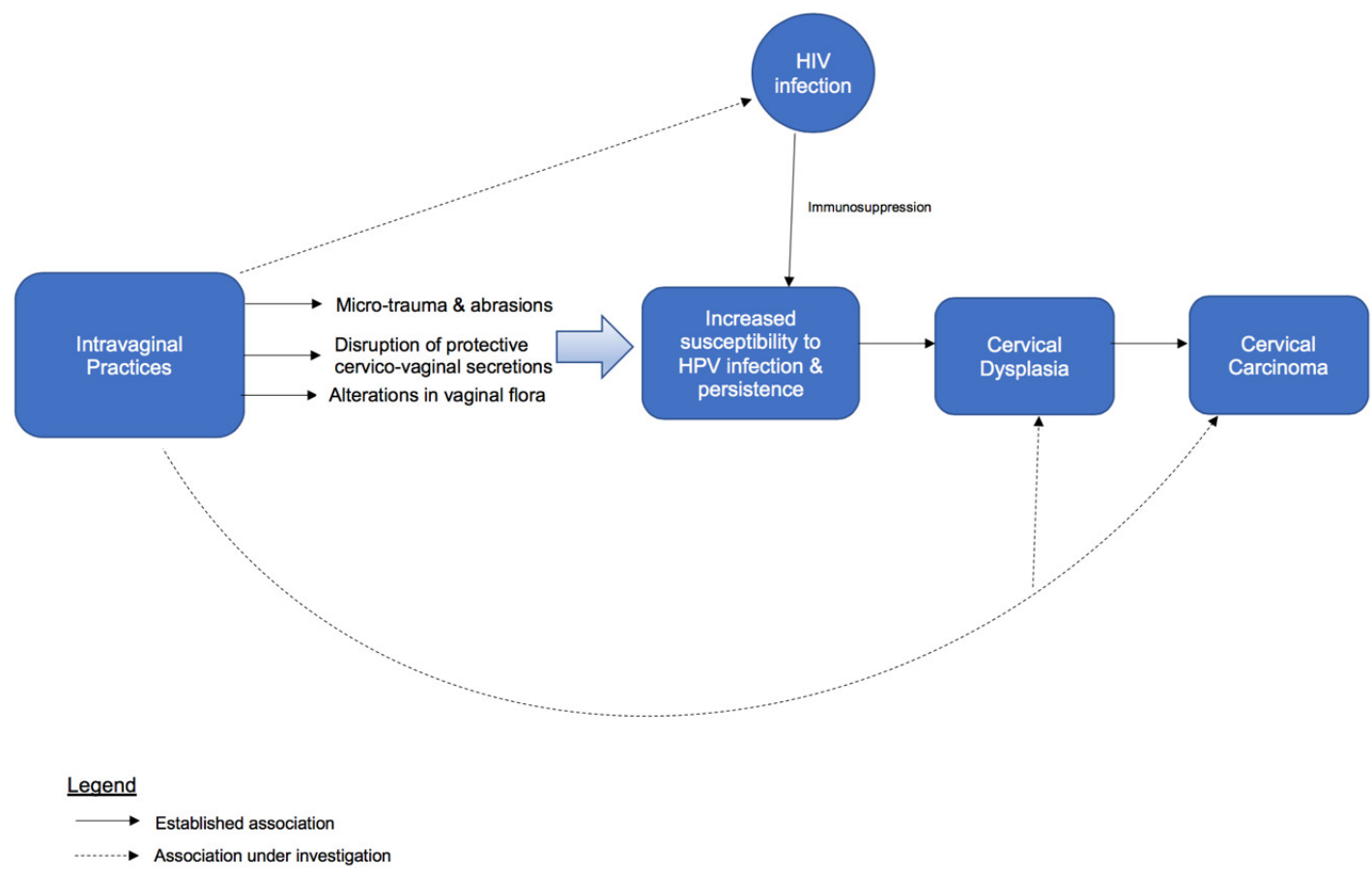

Figure 1. Possible associations between intravaginal practices, HPV infection, cervical cancer \& HIV infection.

ument.

\section{STUDY SELECTION}

References were imported into EndNote Reference Manager X8 (Clarivate Analytics, Philadelphia PA, USA) and titles and abstracts were screened independently by two reviewers (TM and RH). Any discrepancies were resolved by discussion. The same method was used for full-text screening.

\section{DATA COLLECTION PROCESS}

Using a data extraction form designed using guidelines set out by Cochrane ${ }^{17}$ and subsequently piloted on five studies and revised, data was extracted by a single reviewer (TM) and checked by a second (RH). Data was extracted on study authors, study design, year of publication and conduct of the study - the country, number and characteristics of study participants, the definition of intravaginal practices as described in the study, length of follow-up and timing if applicable and the outcome measures used in the study including the method of HPV diagnosis and results as given by effect measures.

\section{QUALITY ASSESSMENT}

The Appraisal Tool for Cross-Sectional Studies (AXIS) and the Newcastle-Ottawa Scale (NOS) for cohort and case-control studies were used to assess quality. ${ }^{18,19}$ This was undertaken by one reviewer (TM) and checked by a second (RH), with discussion for consensus. However, studies were included in the analysis regardless of the quality, with consideration of the limitation on the strength of the conclusions drawn.

\section{PLANNED METHODS OF ANALYSIS}

The marked heterogeneity due to differing definitions of intravaginal practices, variations in study design, participant characteristics and measurement of outcomes precluded undertaking a meta-analysis. Therefore, we carried out a narrative synthesis according to guidelines set out by Popay et al. ${ }^{20}$ Common patterns across studies were combined and components that could potentially have a bearing on risk were evaluated. Where there were both conference abstracts and full-text publications available from a study, the reported findings were drawn from the latter. One conference abstract ${ }^{21}$ was included as an additional study but was not included in the analysis as the full-text publication was not available after contacting the study author.

\section{RISK OF BIAS ACROSS STUDIES}

The weight of evidence cumulatively was assessed using the Evidence for Policy and Practice Information and Coordinating Centre (EPPI) Weight of Evidence Approach through the application of individual weights based on the methodological robustness, appropriateness of study design and relevance. ${ }^{22}$ An overall weighting for each study was assigned by one reviewer (TM) according to the combination of all three. This was checked by a second reviewer (RH), with discussion for consensus, and is presented in Online Supplementary Document.

\section{ETHICS}

As no primary data collection was undertaken, formal ethical approval was not required. A study self-audit was submitted to the Usher Institute Ethics Committee at the Uni- 


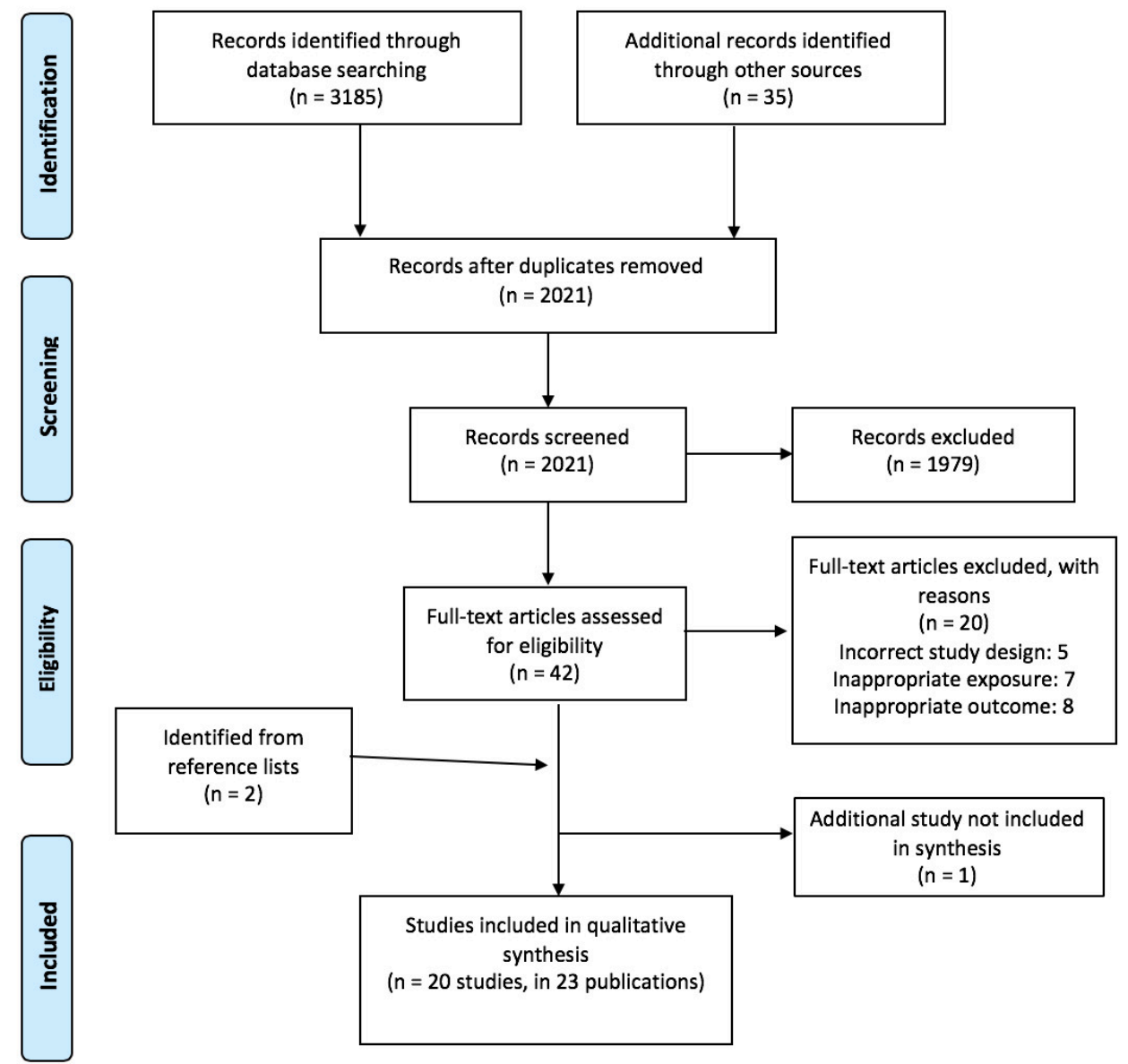

Figure 2. PRISMA flow diagram for study selection.

versity of Edinburgh.

\section{RESULTS \\ STUDY SELECTION}

Figure 2 shows the PRISMA diagram, illustrating the study selection. An initial 3,185 records were identified, of which 2,021 remained after de-duplication. After title and abstract screening, 42 records underwent full-text screening: 18 studies in 21 records were identified as eligible for inclusion. A further two studies were identified through scanning the reference lists of included studies, leading to a total of 20 studies in 23 records for analysis. A full list of excluded studies and reasons for exclusion is provided in Online Supplementary Document.

\section{STUDY CHARACTERISTICS}

The characteristics of individual studies are described in Table 1, categorised according to outcome. Thirteen studies were cross-sectional, ${ }^{23-35}$ five were cohort studies ${ }^{36-40}$ and two were case-control studies, ${ }^{41,42}$ published between 1991 and 2018. In total, they accounted for 14,493 participants. Nine studies were carried out in sub-Saharan Africa
(Democratic Republic of the Congo (DRC), Malawi, Mali, Nigeria, South Africa, Tanzania, Uganda, Zimbabwe), five in Asia (Cambodia, China, South Korea, Taiwan), four in the United States of America (USA), one in Haiti and one in Brazil. The majority (12 studies) included participants recruited from health care settings such as clinics and hospitals, ${ }^{28,32-42}$ and four ${ }^{23,25-27}$ were based on female sex worker (FSW) cohorts. One study included adolescent participants before reported sexual debut. ${ }^{29}$

IVPs described varied in description, detail and substances used (if recorded). Douching was most commonly studied, analysed in ten studies, with three from Asia, ${ }^{30,32,37}$ three from the USA, ${ }^{33,38,41}$ two from sub-Saharan Africa, ${ }^{25,42}$ one from Haiti ${ }^{31}$ and one from Brazil. ${ }^{40}$ However, a definition in keeping with that proposed by the WHO GSVP ${ }^{1}$ was only provided in one study ${ }^{42}$ while the others solely stated douching as the IVP under investigation. Two other studies which were reportedly evaluating douching had definitions more aligned with general intravaginal cleansing and were hence analysed with this group. ${ }^{24,26}$ Intravaginal cleansing and intravaginal insertion were heavily skewed towards sub-Saharan Africa, described in seven studies from this region ${ }^{27-29,34-36,39}$ and in one additional study from Cambodia. ${ }^{23}$ 
Table 1: Characteristics of included studies

\begin{tabular}{|c|c|c|c|c|c|c|c|}
\hline $\begin{array}{l}\text { Author, } \\
\text { year of } \\
\text { publication }\end{array}$ & Country & $\begin{array}{l}\text { Study } \\
\text { design }\end{array}$ & Participants & Age & Intravaginal practice & Outcome & $\begin{array}{l}\text { Study } \\
\text { quality* }\end{array}$ \\
\hline \multicolumn{8}{|c|}{ HPV infection } \\
\hline $\begin{array}{l}\text { Bui et. al, } \\
2018\end{array}$ & Cambodia & $\begin{array}{l}\text { Cross- } \\
\text { sectional }\end{array}$ & $200 \mathrm{FSWs}$ & $\begin{array}{l}\text { Mean } \\
26.7 \\
\text { Range } \\
18-35\end{array}$ & $\begin{array}{l}\text { Intravaginal washing } \\
\text { Intravaginal wiping } \\
\text { Intravaginal insertion }\end{array}$ & $\begin{array}{l}\text { HPV infection (number of } \\
\text { infecting HPV genotypes) }\end{array}$ & Moderate \\
\hline $\begin{array}{l}\text { Bui et. al, } \\
2016\end{array}$ & USA & $\begin{array}{l}\text { Cross- } \\
\text { sectional }\end{array}$ & $\begin{array}{l}1271 \text { women participating in a national } \\
\text { survey }\end{array}$ & $\begin{array}{l}\text { Range } \\
20-49\end{array}$ & Douching ${ }^{\dagger}$ & $\begin{array}{l}\text { HPV infection (number of } \\
\text { infecting HPV DNA types) }\end{array}$ & Moderate \\
\hline $\begin{array}{l}\text { Ebrahim et. } \\
\text { al, } 2016\end{array}$ & $\begin{array}{l}\text { South } \\
\text { Africa }\end{array}$ & Cohort & $\begin{array}{l}224 \text { young women attending primary } \\
\text { health care clinics }\end{array}$ & $\begin{array}{l}\text { Median } \\
21 \\
\text { Range } \\
14-30 \\
\end{array}$ & Vaginal insertion practices & HPV prevalence & Moderate \\
\hline $\begin{array}{l}\text { Esber et. al, } \\
2016 \text { (full } \\
\text { publication) } \\
\text { Esber et. al, } \\
2015 \\
\text { (conference } \\
\text { abstract) }\end{array}$ & Malawi & $\begin{array}{l}\text { Cross- } \\
\text { sectional }\end{array}$ & 200 care-seeking women & $\begin{array}{l}\text { Median } \\
33\end{array}$ & $\begin{array}{l}\text { Intravaginal cleansing } \\
\text { Intravaginal insertion }\end{array}$ & $\begin{array}{l}\text { High-risk HPV infection, bacterial } \\
\text { vaginosis, HSV-2 infection }\end{array}$ & Moderate \\
\hline $\begin{array}{l}\text { Houlihan et. } \\
\text { al, } 2014 \\
\text { (full } \\
\text { publication) } \\
\text { Houlihan et. } \\
\text { al, } 2013 \\
\text { (conference } \\
\text { abstract) }\end{array}$ & Tanzania & $\begin{array}{l}\text { Cross- } \\
\text { sectional }\end{array}$ & $\begin{array}{l}474 \text { adolescent girls before reported } \\
\text { sexual debut }\end{array}$ & $\begin{array}{l}\text { Range } \\
15-16\end{array}$ & $\begin{array}{l}\text { Intravaginal cleansing } \\
\text { Intravaginal insertion }\end{array}$ & HPV infection & Moderate \\
\hline $\begin{array}{l}\text { Lee et. al, } \\
2014\end{array}$ & $\begin{array}{l}\text { South } \\
\text { Korea }\end{array}$ & $\begin{array}{l}\text { Cross- } \\
\text { sectional }\end{array}$ & 912 women in a twin cohort & $\begin{array}{l}\text { Range } \\
25-79\end{array}$ & Douching & HPV infection & Moderate \\
\hline $\begin{array}{l}\text { Moscicki et. } \\
\text { al, } 2013\end{array}$ & USA & Cohort & $\begin{array}{l}1543 \text { women, part of an HPV natural } \\
\text { history study recruited from clinic sites }\end{array}$ & $\begin{array}{l}\text { Range } \\
13-21\end{array}$ & Douching & $\begin{array}{l}\text { HPV16 DNA redetection on } \\
\text { cervical sample }\end{array}$ & High \\
\hline $\begin{array}{l}\text { Seay et. al, } \\
2017 \\
\text { (full } \\
\text { publication) } \\
\text { Kish et. al, } \\
2011\end{array}$ & Haiti & $\begin{array}{l}\text { Cross- } \\
\text { sectional }\end{array}$ & $\begin{array}{l}416 \text { women recruited by Community } \\
\text { Health Workers }\end{array}$ & $\begin{array}{l}\text { Range } \\
26-40\end{array}$ & $\begin{array}{l}\text { "Twalet deba", Haitian Creole } \\
\text { term, use of agents and water to } \\
\text { produce an infusion for } \\
\text { douching }\end{array}$ & High-risk HPV infection & High \\
\hline
\end{tabular}




\begin{tabular}{|c|c|c|c|c|c|c|c|}
\hline $\begin{array}{l}\text { Author, } \\
\text { year of } \\
\text { publication }\end{array}$ & Country & $\begin{array}{l}\text { Study } \\
\text { design }\end{array}$ & Participants & Age & Intravaginal practice & Outcome & $\begin{array}{l}\text { Study } \\
\text { quality* }\end{array}$ \\
\hline \multicolumn{8}{|l|}{$\begin{array}{l}\text { (conference } \\
\text { abstract) }\end{array}$} \\
\hline $\begin{array}{l}\text { Shaw et. al, } \\
2016\end{array}$ & Brazil & Cohort & $\begin{array}{l}1867 \text { women recruited from a maternal } \\
\text { and child health program }\end{array}$ & $\begin{array}{l}\text { Mean } \\
32.9\end{array}$ & Douching & $\begin{array}{l}\text { HPV 1-year period prevalence; } \\
\text { transient HPV infection, } \\
\text { persistent HPV infection }\end{array}$ & Moderate \\
\hline $\begin{array}{l}\text { Sun et. al, } \\
2005\end{array}$ & Taiwan & $\begin{array}{l}\text { Cross- } \\
\text { sectional }\end{array}$ & $\begin{array}{l}1264 \text { women attending gynaecologic } \\
\text { clinics, with abnormal cervical cytology }\end{array}$ & $\begin{array}{l}\text { Median } \\
44 \\
\text { Range } \\
16-85\end{array}$ & Douching, post-coital & HPV prevalence & Low \\
\hline $\begin{array}{l}\text { Tarkowski } \\
\text { et. al, } 2004\end{array}$ & USA & $\begin{array}{l}\text { Cross- } \\
\text { sectional }\end{array}$ & $\begin{array}{l}312 \text { urban adolescent girls recruited } \\
\text { from a clinic }\end{array}$ & $\begin{array}{l}\text { Mean } \\
16.1 \\
\text { Range } \\
12.8- \\
19.9\end{array}$ & Douching & HPV infection & Low \\
\hline \multicolumn{8}{|c|}{ Cervical disease } \\
\hline $\begin{array}{l}\text { Ali-Risasi et. } \\
\text { al, } 2015\end{array}$ & DRC & $\begin{array}{l}\text { Cross- } \\
\text { sectional }\end{array}$ & $\begin{array}{l}1018 \text { women recruited from HIV } \\
\text { screening centres, hospitals \& health } \\
\text { centres }\end{array}$ & $\begin{array}{l}\text { Mean } \\
43.0 \\
\text { Range } \\
17-82 \\
\end{array}$ & $\begin{array}{l}\text { Intravaginal application of } \\
\text { plants/vegetable products or } \\
\text { chemicals for vaginal care }\end{array}$ & LSIL or worse & Moderate \\
\hline $\begin{array}{l}\text { Bayo et. al, } \\
2002\end{array}$ & Mali & $\begin{array}{l}\text { Case- } \\
\text { control }\end{array}$ & $\begin{array}{l}\text { Hospital-based; } 82 \text { cases (invasive } \\
\text { cervical cancer), } 97 \text { hospital controls } \\
\text { matched by } 5 \text {-year age groups }\end{array}$ & $\begin{array}{l}\text { Mean } \\
47 \\
\text { Range } \\
25-56 \\
\text { and } \\
\text { older }\end{array}$ & Douching & Invasive cervical cancer & Moderate \\
\hline $\begin{array}{l}\text { Chu et. al, } \\
2011\end{array}$ & Taiwan & Cohort & $\begin{array}{l}1332 \text { women with abnormal Pap smear } \\
\text { results in medical centres, follow-up of } \\
295 \text { with colposcopy-confirmed LSIL }\end{array}$ & $\begin{array}{l}\text { Not } \\
\text { stated }\end{array}$ & Douching, post-coital & $\begin{array}{l}\text { LSIL non-regression, LSIL } \\
\text { progression }\end{array}$ & High \\
\hline $\begin{array}{l}\text { Gardner et. } \\
\text { al, } 1991\end{array}$ & USA & $\begin{array}{l}\text { Case- } \\
\text { control }\end{array}$ & $\begin{array}{l}266 \text { cases (in-situ and invasive cervical } \\
\text { carcinoma), } 408 \text { group-matched } \\
\text { controls }\end{array}$ & $\begin{array}{l}\text { Range } \\
20-59\end{array}$ & Douching & $\begin{array}{l}\text { In-situ and invasive cervical } \\
\text { carcinoma }\end{array}$ & Moderate \\
\hline $\begin{array}{l}\text { Mbizvo et. } \\
\text { al, } 2005\end{array}$ & Zimbabwe & $\begin{array}{l}\text { Cross- } \\
\text { sectional }\end{array}$ & $\begin{array}{l}200 \text { Mother and Child Health clinic } \\
\text { attendees }\end{array}$ & $\begin{array}{l}\text { Range } \\
15-49\end{array}$ & $\begin{array}{l}\text { Intravaginal cleansing } \\
\text { Use of intravaginal herbs }\end{array}$ & $\begin{array}{l}\text { Cervical dyskaryosis (mild, } \\
\text { moderate, severe) }\end{array}$ & Low \\
\hline $\begin{array}{l}\text { Sagay et. al, } \\
2009\end{array}$ & Nigeria & $\begin{array}{l}\text { Cross- } \\
\text { sectional }\end{array}$ & $\begin{array}{l}374 \mathrm{FSWs} \text { recruited from brothels in the } \\
\text { urban centre of Jos }\end{array}$ & $\begin{array}{l}\text { Mean } \\
27.8 \\
\text { Range }\end{array}$ & Douching & Cervical dysplasia, SILs & Low \\
\hline
\end{tabular}




\begin{tabular}{|c|c|c|c|c|c|c|c|}
\hline $\begin{array}{l}\text { Author, } \\
\text { year of } \\
\text { publication }\end{array}$ & Country & $\begin{array}{l}\text { Study } \\
\text { design }\end{array}$ & Participants & Age & Intravaginal practice & Outcome & $\begin{array}{l}\text { Study } \\
\text { quality* }\end{array}$ \\
\hline & & & & $16-63$ & & & \\
\hline $\begin{array}{l}\text { van de } \\
\text { Wijgert et. } \\
\text { al, } 2000\end{array}$ & Zimbabwe & Cohort & $\begin{array}{l}169 \text { women recruited from family } \\
\text { planning, primary care and postnatal } \\
\text { clinics }\end{array}$ & $\begin{array}{l}\text { Mean } \\
\text { age } 30 \\
\text { Range } \\
18-45\end{array}$ & $\begin{array}{l}\text { Finger-cleansing, wiping and } \\
\text { inserting traditional substances }\end{array}$ & $\begin{array}{l}\text { Colposcopic lesions, HIV \& other } \\
\text { STIs, dysplasia on Pap smear (CIN I } \\
\text { to III or invasive cervical cancer) }\end{array}$ & Moderate \\
\hline \multicolumn{8}{|c|}{ HIV infection } \\
\hline $\begin{array}{l}\text { Luo et. al, } \\
2016\end{array}$ & China & $\begin{array}{l}\text { Cross- } \\
\text { sectional }\end{array}$ & 837 FSWs & $\begin{array}{l}\text { Median } \\
23 \\
\text { Range } \\
16-52\end{array}$ & Douching $^{\dagger}$ & $\begin{array}{l}\text { HIV/STIs (N. gonorrhoeae, C. } \\
\text { trachomatis, T. pallidum, T. vaginalis, } \\
\text { HSV-2 seropositive) }\end{array}$ & Moderate \\
\hline $\begin{array}{l}\text { Vandepitte } \\
\text { et. al, } 2011\end{array}$ & Uganda & $\begin{array}{l}\text { Cross- } \\
\text { sectional }\end{array}$ & $\begin{array}{l}1027 \text { women with high-risk sexual } \\
\text { behaviour (commercial sex work or } \\
\text { employed in entertainment facilities) }\end{array}$ & $\begin{array}{l}\text { Mean } \\
\text { age } 26\end{array}$ & Vaginal cleansing & HIV seroprevalence & High \\
\hline
\end{tabular}

"Quality assessment was carried out using the Appraisal Tool for Cross-Sectional Studies (AXIS), and the Newcastle-Ottawa Scale (NOS) for case-control and cohort studies "Quality assessment was carried out using the Apprais

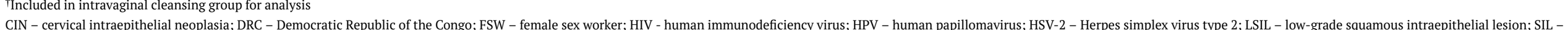
squamous intraepithelial lesion; STI - sexually transmitted infection; USA - United States of America 
Substances were frequently water-based with the addition of natural and commercial products such as salt, lemon or lime juice, vinegar, plant-based agents, medical disinfectant, toothpaste and soap. $23,25,26,28,29,34,37$ The purpose for conducting IVPs where recorded was cited as hygiene most frequently, both for general cleanliness and around sexual intercourse. ${ }^{26,27,41}$ Other reasons were for infection prevention or management and for contraception. ${ }^{25-27,41}$ Intravaginal insertion was practised using herbs acquired from traditional healers, alum, tobacco and other powders, castor oil and medications, with the main purpose being for drying, tightening and warming the vagina prior to sexual intercourse. ${ }^{27-29,36,39}$ The method of application was only mentioned in three studies, commonly the use of fingers, cotton wool or cloth. $28,29,36$

Studies assessed IVPs in relation to the three outcomes of interest; 11 examined HPV infection, seven examined cervical disease and two examined HIV infection, in all cases either as the primary focus or as part of an assessment of multiple risk factors.

\section{QUALITY ASSESSMENT}

Using the AXIS tool, which comprises a checklist of 20-items for overall assessment without the assignment of a score, two cross-sectional studies were assessed as high quality, ${ }^{27,31}$ seven as moderate $23,24,26,28-30,34$ and four as low quality. ${ }^{25,32,33,35}$ Using the NOS, the included casecontrol studies were both assessed as moderate quality. ${ }^{41,42}$ Two cohort studies were assessed as high quality 37,38 and three were moderate. ${ }^{36,39,40}$ Detailed quality assessments are provided in Online Supplementary Document.

\section{INTRAVAGINAL PRACTICES AND HPV INFECTION}

Eleven studies examined the association between IVPs and HPV infection, of which six assessed douching $30-33,38,40$ and five assessed intravaginal cleansing and insertion (Table 2). ${ }^{23,24,28,29,39}$ A clear definition of the IVP was only given in five studies. ${ }^{23,24,28,29,31}$ The prevalence of intravaginal insertion was much less than that observed for intravaginal cleansing, ranging from $0.2-32.1 \%$ and 20.9-94\% respectively, ${ }^{23,29,39}$ while that of douching ranged from $41.3-97.1 \% .{ }^{31,33}$ Most studies focused on the likelihood of HPV detection and prevalence, which ranged from $7.9 \%$ in a South Korean study to $76.3 \%$ in a study conducted in South Africa, ${ }^{30,39}$ with the exception of one study assessing the likelihood of HPV redetection after documented clearance. ${ }^{38}$

Six studies demonstrated evidence of a harmful association, with the greatest effect measure recorded from a study conducted in Haiti with an adjusted odds ratio (OR) of 5.01 (95\% CI 1.56-16.05), between douching with a pigeon pea infusion and HPV infection. ${ }^{31}$ Four found moderate associations, with one finding that douching was significantly associated with infection with a higher number of HPV subtypes, ${ }^{24}$ and the remaining three reported associations with increased risk of HPV infection and prevalence. ${ }^{29,32,33}$ Douching was also associated with a higher likelihood of HPV type-16 (high-risk subtype) redetection. ${ }^{38}$ One study showed an association between IVPs and HPV prior to sexual debut (OR 2.19, 95\% CI 1.09-4.39), although the authors proposed that this might be due to underreporting of self-reported sexual activity. ${ }^{29}$

Protective associations were suggested in two studies: one found frequent douching was associated with a lower prevalence of HPV infection; the other found that regular intravaginal washing, especially when occurring post-coital was associated with infection with lower numbers of HPV subtypes. ${ }^{23,30}$ There was no evidence to support an association between douching, intravaginal cleansing or insertion and HPV infection in two studies. ${ }^{28,40}$ The negative finding for intravaginal insertion may have been due to the low prevalence reported in the study populations; $5 \%$ in Malawi and $5.5 \%$ in Cambodia, which were likely underpowered to detect associations. ${ }^{23,28}$

\section{INTRAVAGINAL PRACTICES AND CERVICAL DISEASE}

Cervical disease was assessed on the spectrum from lowto high-grade dysplasia and subsequent invasive cervical carcinoma, with seven studies examining associations with IVPs (Table 3), of which three provided clear definitions of the IVPs under investigation. ${ }^{34,36,42}$ Four studies assessed douching $25,37,41,42$ and three assessed intravaginal cleansing and insertion. ${ }^{34-36}$ The prevalence of cervical changes varied from $6.1 \%$ in Taiwan ${ }^{37}$ to $24.6 \%$ in Nigeria. ${ }^{25}$

Of the four studies evaluating douching, three found this practice to be associated with a higher risk of cervical disease. One study carried out among a female sex worker (FSW) cohort in Nigeria found that although vaginal douching with lemon or lime juice was significantly associated with the detection of high-grade squamous intraepithelial lesion (HSIL) (OR 2.13, 95\% CI 1.03-4.40, $P=0.025$ ), the strength of this association lessened when combined with low-grade squamous intraepithelial lesion (LSIL) (OR 1.76, $95 \%$ CI $1.0-3.10, P=0.042) .{ }^{25}$ In a study examining douching and carried out in the USA, douching frequency ( $>4$ times/ month) was found to be associated with increased risk of insitu and invasive cervical carcinoma (adjusted OR 4.7, 95\% CI 1.9-11). ${ }^{41}$ In another study, carried out in Taiwan, although douching after sexual intercourse was found to be associated with the non-regression of LSIL, this was not maintained as a risk factor for progression. ${ }^{37}$

Two out of three studies found evidence of a harmful association between intravaginal cleansing and insertion, and cervical disease. Use of herbs for intravaginal insertion in Zimbabwe was found to be associated with cervical dyskaryosis (aOR 2.16, 95\%CI 1.18-4.61). ${ }^{35}$ Similarly, insertion of plant products was associated with LSIL or poorer outcomes in a study in the DRC (aOR 2.70, 95\% CI 1.04-7.01). ${ }^{34}$ A third study, although suggestive of a positive association for the use of finger cleansing, intravaginal wiping and inserting traditional substances with dysplasia on Pap smear, did not reach significance in adjusted analyses (RR 2.42, 95\%CI 1.00-5.90, $P=0.050$ ). ${ }^{36}$ Use of IVPs was almost universal in this study population, which may have limited the ability to detect associations. ${ }^{36}$ 
Table 2: Study results - HPV infection

\begin{tabular}{|c|c|c|c|c|}
\hline $\begin{array}{l}\text { Author, year of } \\
\text { publication, } \\
\text { country }\end{array}$ & Outcome & $\begin{array}{l}\text { Outcome } \\
\text { prevalence } \\
\text { (\%) }\end{array}$ & $\begin{array}{l}\text { Intravaginal } \\
\text { practice \& } \\
\text { prevalence (\%) }\end{array}$ & Effect measure of association \\
\hline $\begin{array}{l}\text { Bui et. al, } 2018 \\
\text { Cambodia }\end{array}$ & $\begin{array}{l}\text { HPV infection (number of infecting } \\
\text { HPV genotypes) }\end{array}$ & 47.0 & $\begin{array}{l}\text { Intravaginal } \\
\text { washing: } 90 \\
\text { Intravaginal } \\
\text { wiping: } 29 \\
\text { Intravaginal } \\
\text { insertion: } 5.5\end{array}$ & $\begin{array}{l}\text { Ever performed intravaginal washing: IRR } 0.59[95 \% \mathrm{Cl} 0.41-0.85], P=0.005 \\
\text { Often performed intravaginal washing shortly before vaginal sex in lifetime: IRR } 0.92[95 \% \mathrm{Cl} \\
0.85-1.01], P=0.086 \\
\text { Often performed intravaginal washing shortly after vaginal sex in lifetime: IRR } 0.88[95 \% \mathrm{Cl} \\
0.81-0.97], P=0.007 \\
\text { No significant associations for the solution used for intravaginal washing } \\
\text { Ever performed intravaginal wiping: IRR } 0.82 \text { [ } 95 \% \mathrm{Cl} 0.60-1.12], P=0.208 \\
\text { No significant associations for performing intravaginal wiping before/after vaginal sex } \\
\text { No significant associations for frequency of intravaginal wiping } \\
\text { Ever performed intravaginal insertion: IRR } 0.81 \text { [ } 95 \% \mathrm{Cl} 0.43-1.52]\end{array}$ \\
\hline $\begin{array}{l}\text { Bui et. al, } 2016 \\
\text { USA }\end{array}$ & $\begin{array}{l}\text { HPV infection (number of infecting } \\
\text { HPV DNA types) }\end{array}$ & 48.6 & Douching*: 23 & $\begin{array}{l}\text { Douched in past } 6 \text { months } \& \text { higher number of HPV DNA types: RRR } 1.56 \text { [ } 95 \% \mathrm{Cl} 1.28-1.90] \text {, } \\
P<0.001 \\
\text { Frequency of douching in the past } 6 \text { months (unadjusted analyses): } \\
<1 \text { time/month ( } 82 \text { participants): RRR } 1.49 \text { [1.09- } 2.05], P=0.013 \\
1 \text { time/month ( } 91 \text { participants): RRR } 1.54 \text { [1.14 - 2.09], } P=0.005 \\
2-4 \text { times/month ( } 85 \text { participants): RRR } 1.63[1.21-2.21], P=0.002 \\
5 \text { or more/month (7 participants): RRR } 1.77 \text { [0.71 - 4.42], } P=0.22\end{array}$ \\
\hline $\begin{array}{l}\text { Ebrahim et. al, } \\
2016 \\
\text { South Africa }\end{array}$ & HPV prevalence & 76.3 & $\begin{array}{l}\text { Vaginal } \\
\text { insertion } \\
\text { practices: } 32.1\end{array}$ & $\begin{array}{l}\text { Vaginal insertion practices \& HPV infection: } \\
\text { Crude OR: } 2.12(95 \% \mathrm{Cl} 1.02-4.41), P=0.045 \\
\text { Adjusted OR: } 1.98[95 \% \mathrm{Cl} 0.88-4.48], P=0.099\end{array}$ \\
\hline $\begin{array}{l}\text { Esber et. al, } \\
2016 \text { (full } \\
\text { publication) } \\
\text { Malawi }\end{array}$ & High-risk HPV infection & 22 & $\begin{array}{l}\text { Intravaginal } \\
\text { cleansing: } \\
\text { - With soap \& wa- } \\
\text { ter: } 47 \\
\text { With cotton, } \\
\text { cloth or tissue: } \\
94 \\
\text { Intravaginal } \\
\text { insertion: } 5\end{array}$ & $\begin{array}{l}\text { Cleansing with soap and water: } \mathrm{PR} 1.03 \text { [95\% Cl } 0.51-2.08] \\
\text { Cleansing with cotton, cloth or tissue: PR } 0.73 \text { [95\% Cl } 0.25-2.08] \\
\text { Other products: } \mathrm{PR} 1.96[95 \% \mathrm{Cl} 0.69-5.5] \\
\text { IVP frequency and hr-HPV: } \\
\text { - Any IVP: PR } 0.98[95 \% \mathrm{Cl} 0.52-1.85] \\
\text { - Soap and water: PR } 0.48[95 \% \mathrm{Cl} 0.19-1.20]\end{array}$ \\
\hline $\begin{array}{l}\text { Houlihan et. al, } \\
2014 \text { (full } \\
\text { publication) } \\
\text { Tanzania }\end{array}$ & HPV infection & 8.4 & $\begin{array}{l}\text { Intravaginal } \\
\text { cleansing: } 20.9 \\
\text { Intravaginal } \\
\text { insertion: } 0.2\end{array}$ & $\begin{array}{l}\text { Intravaginal cleansing: aOR } 2.19 \text { [ } 95 \% \mathrm{Cl} 1.09 \text { - 4.39] } \\
\text { Dose-response relationship between cleansing frequency and HPV DNA detection: aOR } 1.54 \\
{[95 \% \mathrm{Cl} 1.17-2.03]}\end{array}$ \\
\hline $\begin{array}{l}\text { Lee et. al, } 2014 \\
\text { South Korea }\end{array}$ & HPV infection & 7.9 & Douching: 92.5 & $\begin{array}{l}\text { Douching: } \\
\text { - Every other day or more: OR } 0.32[95 \% \mathrm{Cl} 0.13-0.77] \\
\text { - } 1-2 \text { times/month: OR } 1.79[95 \% \mathrm{Cl} 0.13-24.38]\end{array}$ \\
\hline Moscicki et. al, & HPV16 DNA redetection on cervical & 18.1 & Douching: Not & Association of douching with redetection of human papillomavirus Type 16 (HPV16) DNA \\
\hline
\end{tabular}




\begin{tabular}{|c|c|c|c|c|}
\hline $\begin{array}{l}\text { Author, year of } \\
\text { publication, } \\
\text { country }\end{array}$ & Outcome & $\begin{array}{l}\text { Outcome } \\
\text { prevalence } \\
\text { (\%) }\end{array}$ & $\begin{array}{l}\text { Intravaginal } \\
\text { practice \& } \\
\text { prevalence (\%) }\end{array}$ & Effect measure of association \\
\hline $\begin{array}{l}2013 \\
\text { USA }\end{array}$ & sample & $\begin{array}{l}\text { redetection } \\
\text { within } 8.5 \\
\text { years }\end{array}$ & reported & $\begin{array}{l}\text { Among Women who had evidence of HPV16 DNA infection and clearance: aOR } 2.35 \text { [ } 95 \% \mathrm{Cl} \\
1.02-5.41]\end{array}$ \\
\hline $\begin{array}{l}\text { Seay et. al, } \\
2017 \\
\text { (full } \\
\text { publication) } \\
\text { Haiti }\end{array}$ & High-risk HPV infection & 11 & Douching: 97.1 & Douching with pigeon pea infusion \& high-risk HPV: aOR 5.01 [95\% Cl $1.56-16.05]$ \\
\hline $\begin{array}{l}\text { Shaw et. al, } \\
2016 \\
\text { Brazil }\end{array}$ & $\begin{array}{l}\text { HPV 1-year period prevalence; } \\
\text { transient HPV infection, persistent } \\
\text { HPV infection }\end{array}$ & 39.3 & $\begin{array}{l}\text { Douching: Not } \\
\text { reported }\end{array}$ & $\begin{array}{l}\text { Douching frequent vs. infrequent \& Subgenus } 2 \text { (carcinogenic) HPV: OR } 1.29 \text { [ } 95 \% \mathrm{Cl} 0.83 \text { - } \\
2.00] \\
\text { Douching frequent vs. infrequent: OR } 1.10 \text { [ } 95 \% \mathrm{Cl} 0.60-2.00] \text { for transient infection, } 1.12 \\
\text { [95\% Cl } 0.62-2.01 \text { f for persistent infection } \\
\text { No association for substance used (Natural/Medical/Unknown) }\end{array}$ \\
\hline $\begin{array}{l}\text { Sun et. al, } 2005 \\
\text { Taiwan }\end{array}$ & HPV prevalence & 68.5 & Douching: 64.7 & $\begin{array}{l}\text { Frequent vaginal douching: OR } 1.48[95 \% \mathrm{Cl} 1.12-1.97] \\
\qquad \text { With tap water OR } 1.426[95 \% \mathrm{Cl} 1.08-1.89] \\
\text { • With normal saline or detergent OR } 2.230[95 \% \mathrm{Cl} 1.08-4.61] \\
\text { Vaginal douche after sexual intercourse: aOR } 1.48[95 \% \mathrm{Cl} 1.12-1.97]\end{array}$ \\
\hline $\begin{array}{l}\text { Tarkowski et. } \\
\text { al, } 2004 \\
\text { USA }\end{array}$ & HPV infection & 64 & Douching: 41.3 & $\begin{array}{l}\text { Douching during the last } 90 \text { days: aOR } 2.1[95 \% \mathrm{Cl} 1.2-3.6] \\
\text { Douching frequency during the last } 90 \text { days } \\
\text { - } 0 \text { : OR } 1.6[95 \% \mathrm{Cl} 0.9-3.1] \\
\text { - } 1 \text { or } 2: \text { OR } 2.6[95 \% \mathrm{Cl} 1.4-5.0] \\
\text { - } 3 \text { or more: } \mathrm{OR} 5.2[95 \% \mathrm{Cl} 2.4-11.2]\end{array}$ \\
\hline
\end{tabular}

aOR - adjusted odds ratio; HPV - human papillomavirus; hrHPV - high risk human papillomavirus; IRR - incidence rate ratio; OR - odds ratio; PR - prevalence ratio; RRR - relative risk ratio; $95 \%$ CI - 95\% confidence interval 
Table 3: Study results - cervical disease

\begin{tabular}{|c|c|c|c|c|}
\hline $\begin{array}{l}\text { Author, } \\
\text { year of } \\
\text { publication, } \\
\text { country }\end{array}$ & Outcome & $\begin{array}{l}\text { Outcome } \\
\text { prevalence } \\
\text { (\%) }\end{array}$ & $\begin{array}{l}\text { Intravaginal } \\
\text { practice \& } \\
\text { prevalence (\%) }\end{array}$ & Effect measure of association \\
\hline $\begin{array}{l}\text { Ali-Risasi } \\
\text { et. al, } 2015 \\
\text { DRC }\end{array}$ & $\begin{array}{l}\text { Low-grade } \\
\text { squamous } \\
\text { intraepithelial } \\
\text { lesions or worse }\end{array}$ & 7.5 & $\begin{array}{l}\text { Use of plants } \\
\text { for vaginal } \\
\text { care: } 11.4 \\
\text { Use of chemical } \\
\text { products for } \\
\text { vaginal care: } \\
26.0\end{array}$ & $\begin{array}{l}\text { Use of plants for vaginal care: aOR } 2.70 \text { [95\% } \\
\mathrm{Cl} 1.04-7.01] \\
\text { Use of chemical products for vaginal care: } \\
\text { aOR } 0.65[95 \% \mathrm{Cl} 0.37-1.14]\end{array}$ \\
\hline $\begin{array}{l}\text { Bayo et. al, } \\
2002 \\
\text { Mali }\end{array}$ & $\begin{array}{l}\text { Invasive Cervical } \\
\text { Carcinoma }\end{array}$ & $\begin{array}{l}\text { N/A, case- } \\
\text { control study }\end{array}$ & $\begin{array}{l}\text { Douching: } \\
\text { - Cases: } 3.7 \\
\text { - Controls: } 29.9\end{array}$ & $\begin{array}{l}\text { Never having practiced vaginal douching \& } \\
\text { cervical cancer: aOR } 17.6 \text { [95\% Cl } 4.2-74.7]\end{array}$ \\
\hline $\begin{array}{l}\text { Chu et. al, } \\
2011 \\
\text { Taiwan }\end{array}$ & $\begin{array}{l}\text { Non-regression or } \\
\text { progression of } \\
\text { LSIL }\end{array}$ & $\begin{array}{l}6.1 \text { non- } \\
\text { regression, } \\
10.5 \\
\text { progression }\end{array}$ & Douching: 65 & $\begin{array}{l}\text { Habit of douching after vaginal intercourse: } \\
\text { OR } 1.89 \text { [95\% Cl } 1.01-3.53] \\
\text { - With tap water: OR } 1.77 \text { [95\% } \mathrm{Cl} 0.94-3.35] \\
\text { - With saline or detergent: OR } 3.14[95 \% \mathrm{Cl} 1.04 \\
-9.49]\end{array}$ \\
\hline $\begin{array}{l}\text { Gardner et. } \\
\text { al, } 1991 \\
\text { USA }\end{array}$ & $\begin{array}{l}\text { In-situ and } \\
\text { invasive cervical } \\
\text { carcinoma }\end{array}$ & $\begin{array}{l}\text { N/A, case } \\
\text { control- } \\
\text { study }\end{array}$ & $\begin{array}{l}\text { Douching: } \\
\text { - Cases: } 69 \\
\text { - Controls: } 31\end{array}$ & $\begin{array}{l}\text { Douching } 10 \text { or more times in the lifetime \& } \\
\text { cervical carcinoma: } \\
\text { - Crude OR } 2.5 \text { [ } 95 \% \mathrm{Cl} 1.8-3.6] \\
\text { - Adjusted OR } 1.3[95 \% \mathrm{Cl} 0.8-1.9] \\
\text { Douching frequency, only }>4 \text { times/month } \\
\text { associated: } \\
\text { - Crude OR } 6.7 \text { [ } 95 \% \mathrm{Cl} 3.6-13] \\
\text { - Adjusted OR } 4.7[95 \% \mathrm{Cl} 1.9-11] \\
\text { No specific douching preparations were } \\
\text { associated with an increased risk }\end{array}$ \\
\hline $\begin{array}{l}\text { Mbizvo et. } \\
\text { al, } 2005 \\
\text { Zimbabwe }\end{array}$ & $\begin{array}{l}\text { Cervical } \\
\text { dyskaryosis (mild, } \\
\text { moderate, severe) }\end{array}$ & $\begin{array}{l}19(16 \text { mild, } \\
1.5 \\
\text { moderate, } \\
1.5 \text { severe })\end{array}$ & $\begin{array}{l}\text { Intravaginal } \\
\text { cleansing: } 48 \\
\text { Use of } \\
\text { intravaginal } \\
\text { herbs: } 27\end{array}$ & $\begin{array}{l}\text { Intravaginal cleansing \& cervical dyskaryosis: } \\
\text { aOR } 2.1[95 \% \mathrm{Cl} 1.10-4.2] \\
\text { Use of intravaginal herbs \& cervical } \\
\text { dyskaryosis: aOR } 2.16[95 \% \mathrm{Cl} 1.18-4.61]\end{array}$ \\
\hline $\begin{array}{l}\text { Sagay et. al, } \\
2009 \\
\text { Nigeria }\end{array}$ & $\begin{array}{l}\text { Squamous } \\
\text { intraepithelial } \\
\text { lesions (SILs) }\end{array}$ & 24.6 & $\begin{array}{l}\text { Douching: } \\
\text { - With lime juice: } \\
90.4 \\
\text { - With lemon } \\
\text { juice: } 14.2\end{array}$ & $\begin{array}{l}\text { Douching with lemon/lime juice \& HSIL: aOR } \\
2.13 \text { [ } 95 \% \mathrm{CI} 1.03-4.40], P=0.025 \\
\text { Douching with lemon/lime juice } \& \text { LSIL/HSIL: } \\
\text { aOR } 1.76[95 \% \mathrm{CI} 1.0-3.10], P=0.042 \\
\text { Cervical dysplasia was not associated with } \\
\text { greater duration of douching with lemon/lime } \\
\text { juice: } P \text {-value for trend }=0.20\end{array}$ \\
\hline $\begin{array}{l}\text { van de } \\
\text { Wijgert et. } \\
\text { al, } 2000 \\
\text { Zimbabwe }\end{array}$ & $\begin{array}{l}\text { Dysplasia on Pap } \\
\text { smear }\end{array}$ & $\begin{array}{l}17.3 \text { in users, } \\
15.3 \text { non- } \\
\text { users at } \\
\text { follow-up }\end{array}$ & $\begin{array}{l}\text { Intravaginal } \\
\text { cleansing: } 96 \\
\text { Intravaginal } \\
\text { insertion: } 47\end{array}$ & $\begin{array}{l}\text { Dysplasia on Pap smear in users vs. non-users: } \\
\text { RR } 3.14 \text { [95\% Cl } 0.85-17.33] \\
\text { On multivariate analysis: OR } 2.42 \text { [ } 95 \% \mathrm{Cl} \\
1.00-5.90]\end{array}$ \\
\hline
\end{tabular}

aOR - adjusted odds ratio; DRC - Democratic Republic of the Congo; HSIL - high-grade squamous intraepithelial lesion; LSIL - low-grade squamous intraepithelial lesion; OR - odds ratio; $95 \%$ CI - 95\% confidence interval

\section{INTRAVAGINAL PRACTICES AND HIV INFECTION}

We identified two studies that examined the association between IVPs and HIV infection (Table 4), both of which provided clear definitions of IVPs. One was carried out in China among female sex workers, the other in Uganda among women involved in high-risk sexual behaviours. ${ }^{26,27}$ Weak positive associations were demonstrated between intravaginal cleansing and HIV prevalence in both studies, finding adjusted odds ratios of 2.29 (95\%CI 1.01-5.23) and 1.32 (95\%CI $1.00-1.73$ ), $P=0.05$ respectively. ${ }^{26,27}$ The use of toothpaste and medical disinfectant were the only statistically significant associations. ${ }^{26}$ Similarly, this was observed for intravaginal cleansing with soap in the Ugandan study. 27

We examined whether or not HIV infection was explored in the studies investigating associations between IVPs with HPV and cervical disease (Online Supplementary Document.): less than half the studies stratified by HIV status; none found a significant relationship.

\section{POTENTIAL MODERATOR VARIABLES}

We examined potential moderator variables for association of IVPs with the outcomes of interest (Table 5).

Seven studies assessing association with HPV infection 
Table 4: Study results - HIV infection

\begin{tabular}{|c|c|c|c|c|}
\hline $\begin{array}{l}\text { Author, year } \\
\text { of } \\
\text { publication, } \\
\text { country }\end{array}$ & Outcome & $\begin{array}{l}\text { Outcome } \\
\text { prevalence } \\
\text { (\%) }\end{array}$ & $\begin{array}{l}\text { Intravaginal } \\
\text { practice \& } \\
\text { prevalence (\%) }\end{array}$ & Effect measure of association \\
\hline $\begin{array}{l}\text { Luo et. al, } \\
2016 \\
\text { China }\end{array}$ & $\begin{array}{l}\text { HIV-1 } \\
\text { seropositivity }\end{array}$ & 10 & Douching: 84 & $\begin{array}{l}\text { Association between vaginal douching \& HIV: } \\
\text { aOR } 2.29 \text { [ } 95 \% \mathrm{Cl} 1.01-5.23] \\
\text { Only douching with toothpaste and medical } \\
\text { disinfectant were associated with significant } \\
\text { increases in HIV risk }\end{array}$ \\
\hline $\begin{array}{l}\text { Vandepitte } \\
\text { et. al, 2011 } \\
\text { Uganda }\end{array}$ & $\begin{array}{l}\text { HIV } \\
\text { seroprevalence }\end{array}$ & 37 & $\begin{array}{l}\text { Intravaginal } \\
\text { cleansing: } 94 \\
\text { Intravaginal } \\
\text { insertion: } 56\end{array}$ & $\begin{array}{l}\text { Cleansing of the vagina using soap and HIV- } \\
\text { infection: aOR } 1.32 \text { [ } 95 \% \mathrm{Cl} 1.00-1.73], P=0.05 \\
\text { Cleansing inside the vagina in the last } 3 \text { months: } \\
\text { aOR } 1.18 \text { [ } 95 \% \mathrm{Cl} 0.66-2.10], P=0.58 \\
\text { Inserting any substance inside the vagina in last } 3 \\
\text { months: aOR } 1.04 \text { [ } 95 \% \mathrm{Cl} 0.79-1.38], P=0.77\end{array}$ \\
\hline
\end{tabular}

aOR - adjusted odds ratio; HIV - human immunodeficiency virus; 95\% CI - 95\% confidence interval

described the substances used, ${ }^{23,28,29,31,32,39,40}$ with all except one,${ }^{39}$ further analysing associations with each of the substances separately. A positive association was demonstrated in two studies: ${ }^{31,32}$ in one, normal saline or detergent use for douching was found to be more harmful than tap water in adjusted analyses; ${ }^{32}$ in the other, an association between douching and a higher risk of HPV infection was found with a pigeon pea infusion. ${ }^{31}$ Four studies did not find statistically significant associations between the substances used for douching, intravaginal cleansing or intravaginal insertion and the risk of HPV infection. ${ }^{23,28,29,40}$ The frequency of IVP use was examined in seven studies, ${ }^{23,24,28-30,33,40}$ with three $24,29,33$ reporting a positive dose-response effect: the higher the frequency of the IVP use, the higher the likelihood of HPV infection. The remaining studies ${ }^{28,30,40}$ did not demonstrate an association between increasing frequency of IVP use and the likelihood of HPV infection, but one found that the highest frequency of douching was protective for HPV infection. ${ }^{30}$

In terms of potential moderators for an association of IVP use and cervical disease, only three studies $34,37,41$ analysed by the specific IVP substance used. One study 37 found higher odds of LSIL non-regression with saline or detergent (OR 3.14, 95\% CI 1.04-9.49) compared to tap water (OR 0.77, 95\% CI 0.94-3.35). Another, ${ }^{41}$ comparison of chemical and commercial solutions, water alone, and water in combination with vinegar or soda found risk did not depend on the substance used. ${ }^{41}$ In the third study, although the use of chemicals was more prevalent than plant products (26\% vs. $11 \%$ ), only plant products had a significant association with the presence of LSIL or more severe lesions, with an adjusted odds ratio of 2.70, 95\% CI 1.04-7.01.34 Two studies $^{25,37}$ reported on timing of IVP use. Post-coital vaginal douching was found to be associated with harm, but no comparisons were made with pre-coital timing. ${ }^{37}$ The second study mentioning timing did not analyse pre-coital and post-coital timing separately and instead considered douching as a whole. ${ }^{25}$ Two studies commented on the duration for which IVPs were used; a study evaluating an FSW cohort noted that although douching with lemon or lime juice was closely associated with the duration for which participants had been employed in commercial sex work, this did not seem to have an impact on the likelihood of cervical disease ${ }^{25}$ the other study, ${ }^{36}$ although reporting on duration did not analyse its impact on the associations.

\section{DISCUSSION}

\section{SUMMARY OF FINDINGS}

Overall, the current evidence base does not allow firm conclusions to be drawn on the association between IVPs, HPV infection or the development of cervical cancer, although there is a broad suggestion of harm. This systematic review included 20 studies in 23 publications of which most were of low to moderate quality. As most studies involved douching, drawing associations between the outcomes of interest and other types of IVPs was limited.

The prevalence of IVPs was high in most study populations, but with wide variation in the specific practice, and by geographic location. Douching or intravaginal cleansing were much more common than intravaginal insertion in general, reflecting findings from previous studies. ${ }^{43-45}$ Eleven out of 18 studies reported an elevated risk of HPV infection, or cervical disease, with IVP use. However, it was not possible to draw firm conclusions of association between HPV infection and either intravaginal cleansing or insertion, similar to findings demonstrated in relation to HIV infection. ${ }^{4}$ In contrast, there is some evidence of increased risk of cervical disease, with both intravaginal cleansing and insertion. 
Table 5: Potential moderator variables - components of IVPs included in each study

\begin{tabular}{|c|c|c|c|c|c|c|c|c|c|}
\hline Author, Year & Outcome & IVP & $\begin{array}{l}\text { Clear } \\
\text { definition } \\
\text { of IVP }\end{array}$ & $\begin{array}{l}\text { Description of } \\
\text { substance used }\end{array}$ & $\begin{array}{l}\text { Method of } \\
\text { application }\end{array}$ & Purpose & Timing & Frequency & Duration \\
\hline \multicolumn{10}{|c|}{ HPV Infection } \\
\hline $\begin{array}{l}\text { Bui et. al, } \\
2018\end{array}$ & HPV & $\begin{array}{l}\text { Intravaginal washing, wiping \& } \\
\text { insertion }\end{array}$ & $\sqrt{ }$ & $\sqrt{ }$ & - & $\sqrt{ }$ & $\sqrt{ }$ & $\sqrt{ }$ & $\sqrt{ }$ \\
\hline $\begin{array}{l}\text { Bui et. al, } \\
2016\end{array}$ & HPV & $\begin{array}{l}\text { Douching (analysed as } \\
\text { intravaginal cleansing) }\end{array}$ & $\sqrt{ }$ & - & - & - & - & $\sqrt{ }$ & - \\
\hline $\begin{array}{l}\text { Ebrahim et. al, } \\
2016\end{array}$ & HPV & $\begin{array}{l}\text { Intravaginal substance use/ } \\
\text { vaginal insertion practice }\end{array}$ & - & $\sqrt{ }$ & - & $\sqrt{ }$ & - & - & - \\
\hline $\begin{array}{l}\text { Esber et. al, } \\
2016\end{array}$ & HPV & $\begin{array}{l}\text { Intravaginal cleansing \& } \\
\text { insertion }\end{array}$ & $\sqrt{ }$ & $\sqrt{ }$ & $\sqrt{ }$ & - & - & $\sqrt{ }$ & - \\
\hline $\begin{array}{l}\text { Houlihan et. } \\
\text { al, } 2014\end{array}$ & HPV & $\begin{array}{l}\text { Intravaginal cleansing \& } \\
\text { insertion }\end{array}$ & $\sqrt{ }$ & $\sqrt{ }$ & $\sqrt{ }$ & - & - & $\sqrt{ }$ & - \\
\hline $\begin{array}{l}\text { Lee et. al, } \\
2014\end{array}$ & HPV & Douching & - & - & - & - & - & $\sqrt{ }$ & - \\
\hline $\begin{array}{l}\text { Moscicki et. } \\
\text { al, } 2013\end{array}$ & HPV redetection & Douching & - & - & - & - & - & - & - \\
\hline $\begin{array}{l}\text { Seay et. al, } \\
2017\end{array}$ & HPV & Douching & $\sqrt{ }$ & $\sqrt{ }$ & $\sqrt{ }$ & $\sqrt{ }$ & - & - & - \\
\hline $\begin{array}{l}\text { Shaw et. al, } \\
2016\end{array}$ & HPV & Douching & - & $\sqrt{ }$ & - & - & - & $\sqrt{ }$ & - \\
\hline $\begin{array}{l}\text { Sun et. al, } \\
2005\end{array}$ & HPV & Douching & - & $\sqrt{ }$ & - & - & $\sqrt{ }$ & - & - \\
\hline $\begin{array}{l}\text { Tarkowski et. } \\
\text { al, } 2004\end{array}$ & HPV & Douching & - & - & - & - & - & $\sqrt{ }$ & - \\
\hline \multicolumn{10}{|c|}{ Cervical disease } \\
\hline $\begin{array}{l}\text { Ali-Risasi et. } \\
\text { al, } 2015\end{array}$ & LSIL or worse & $\begin{array}{l}\text { Plants \& chemicals for vaginal } \\
\text { care }\end{array}$ & $\sqrt{ }$ & $\sqrt{ }$ & - & - & - & - & - \\
\hline $\begin{array}{l}\text { Bayo et. al, } \\
2002\end{array}$ & $\begin{array}{l}\text { Invasive cervical } \\
\text { carcinoma }\end{array}$ & Douching & $\sqrt{ }$ & $\sqrt{ }$ & - & - & - & - & - \\
\hline $\begin{array}{l}\text { Chu et. al, } \\
2011\end{array}$ & $\begin{array}{l}\text { Non-regression or } \\
\text { progression of LSIL }\end{array}$ & Douching & - & $\sqrt{ }$ & - & - & $\sqrt{ }$ & - & - \\
\hline $\begin{array}{l}\text { Gardner et. al, } \\
1991\end{array}$ & $\begin{array}{l}\text { In-situ and invasive } \\
\text { cervical carcinoma }\end{array}$ & Douching & - & $\sqrt{ }$ & - & $\sqrt{ }$ & - & $\sqrt{ }$ & - \\
\hline
\end{tabular}




\begin{tabular}{|c|c|c|c|c|c|c|c|c|c|}
\hline Author, Year & Outcome & IVP & $\begin{array}{l}\text { Clear } \\
\text { definition } \\
\text { of IVP }\end{array}$ & $\begin{array}{l}\text { Description of } \\
\text { substance used }\end{array}$ & $\begin{array}{l}\text { Method of } \\
\text { application }\end{array}$ & Purpose & Timing & Frequency & Duration \\
\hline $\begin{array}{l}\text { Mbizvo et. al, } \\
2005\end{array}$ & Cervical dyskaryosis & $\begin{array}{l}\text { Intravaginal cleansing \& } \\
\text { insertion }\end{array}$ & - & - & - & - & - & - & - \\
\hline $\begin{array}{l}\text { Sagay et. al, } \\
2009\end{array}$ & $\begin{array}{l}\text { Squamous } \\
\text { intraepithelial lesions }\end{array}$ & Douching & - & $\sqrt{ }$ & - & $\sqrt{ }$ & $\sqrt{ }$ & - & $\sqrt{ }$ \\
\hline $\begin{array}{l}\text { van de } \\
\text { Wijgert et. al, } \\
2000\end{array}$ & $\begin{array}{l}\text { Dysplasia on Pap } \\
\text { smear }\end{array}$ & $\begin{array}{l}\text { Intravaginal cleansing, wiping } \\
\text { \& insertion }\end{array}$ & $\sqrt{ }$ & $\sqrt{ }$ & $\sqrt{ }$ & $\sqrt{ }$ & - & - & $\sqrt{ }$ \\
\hline \multicolumn{10}{|c|}{ HIV Infection } \\
\hline $\begin{array}{l}\text { Luo et. al, } \\
2016\end{array}$ & HIV & $\begin{array}{l}\text { Douching (analysed as } \\
\text { intravaginal cleansing) }\end{array}$ & $\sqrt{ }$ & $\sqrt{ }$ & - & $\sqrt{ }$ & - & - & - \\
\hline $\begin{array}{l}\text { Vandepitte } \\
\text { et. al, } 2011\end{array}$ & HIV & $\begin{array}{l}\text { Intravaginal cleansing \& } \\
\text { insertion }\end{array}$ & $\sqrt{ }$ & $\sqrt{ }$ & - & $\sqrt{ }$ & - & - & - \\
\hline
\end{tabular}

Adapted from Popay et. al, 2006 p.3920

$\checkmark$ : given in the study

$-:$ not reported

HIV - human immunodeficiency virus; HPV - human papillomavirus; IVP - intravaginal practice; LSIL - low-grade squamous intraepithelial lesion 


\section{STRENGTHS AND LIMITATIONS OF THE STUDY}

The main strengths of our review included the comprehensive search strategy, and searching of six databases as well as grey literature sources. A diverse range of studies covered varying geographical locations, with the inclusion of over 14,000 participants, and good representation of women from the general population as well as female sex workers. Quality assessment was carried out using validated tools.

Limitations to our systematic review are important to note. At present, most evidence lies in cross-sectional studies and therefore the detection of HPV infection was only limited to recently acquired infections which may have been transient. The inability to establish temporality limited clear understanding of the possible mechanism of association as the persistence of HPV infection is a pre-requisite for progression to cervical cancer. ${ }^{12}$ The substantial heterogeneity brought about by the absence of use of clear definitions for IVPs and detail regarding their specific application also limits an understanding of the potential association. In addition, there is the possibility of attenuated risk occurring where multiple IVPs were undertaken in the same study population, but it was not possible to disaggregate data. Douching was the most frequently studied practice, with limited data on intravaginal cleansing practices or intravaginal insertion: reporting of these may be influenced by social desirability bias. Although the geographical diversity captured is recognised as a strength and similarities were noted across different countries, it is important to acknowledge that certain context-specific nuances with respect to IVPs may not have been comprehensively reflected, given their culturally engrained nature ${ }^{46}$.

\section{EXISTING LITERATURE}

We have identified no previous systematic reviews on IVP use and risk of cervical disease: a meta-analysis from 1997 examined the relationship between douching and cervical cancer and found a marginal association. ${ }^{3}$ That study reported pooled results from six case-control studies with invasive cervical cancer as the outcome and suggested that associations could be related to the preparation used for douching, as well as the frequency and timing. ${ }^{3}$ However, due to the length of time required for the development of cervical cancer, we instead considered possible associations between the acquisition of HPV infection, and subsequent progression to cervical cancer, with a variety of IVPs in addition to douching. Exploration of the effect of potential moderator variables was limited in our review due to the lack of detail in reporting in the primary studies and findings were mixed. The specific substance used for IVPs could possibly contribute to a higher risk of HPV infection or changes leading to persistence and cervical cancer development through the chemical content or degree of abrasiveness. $3,5,47$ In our review, nine studies analysed this variable: four showed evidence of an increased risk. However, there was considerable heterogeneity in the substances assessed, from normal saline, toothpaste and disinfectants to various plant and commercial products.

Similarly, the frequency of undertaking IVPs was inconclusive, likely contributed to by the inconsistencies in defi- nitions for 'frequent' and 'infrequent', with some measuring daily frequency and others assessing conduct of IVPs over a weekly or monthly basis. The frequency of use had been hypothesised to be an important factor in relation to douching and the acquisition of bacterial STIs and other negative outcomes, possibly due to the decreased time for recovery of the vaginal flora with more frequent conduct of IVPs. ${ }^{48}$ Other factors, such as timing and duration of use of IVPs could not be clearly assessed as they were not consistently reported in the included studies.

There is limited new evidence of association of IVPs and HIV infection since 2008, with the identification of only two full-text studies. Consistent with previous findings, ${ }^{9}$ both studies reported harm associated with intravaginal cleansing, ${ }^{26,27}$ but one reported no association with intravaginal insertion. ${ }^{27}$ A conference abstract (excluded at full-text stage), suggests decreased risk of HIV infection with intravaginal cleansing. ${ }^{21}$

\section{IMPLICATIONS}

There is a need for prospective longitudinal studies in populations where IVPs are prevalent, to better understand whether and how IVPs may affect the timeline of progression to cervical cancer, or other gynaecological outcomes. Given that most evidence lies in low to moderate quality studies, future studies should include larger and more representative samples. In addition, consistent use of standardised definitions and categorisations of IVPs, such as those proposed by the WHO GSVP study group, would enable clearer comparisons between populations and regions. ${ }^{1}$ It is essential to limit the effects of social desirability and recall bias in reporting, using contextually and culturally appropriate methods to elicit understanding and reporting of the types of IVPs (such as the self-administered pictorial diary used in Uganda and Tanzania). ${ }^{44}$

Exploration of mediating factors for risk should also be improved. An association between HIV infection and IVPs has been proposed to be related to an increased risk of abnormal flora, in particular bacterial vaginosis which could then facilitate transmission, rather than a direct linkage. ${ }^{4,9}$ Bacterial vaginosis has been investigated in two prior systematic reviews exploring associations with HPV infection as well as with cervical intraepithelial neoplasia. ${ }^{49,50} \mathrm{How}^{-}$ ever, these studies did not investigate IVPs, so there remains scope for investigation of this and other potential mediators.

Although the precise mechanism remains unclear, the extent of the evidence suggestive of harm in the included studies in this review is a cause for concern. In keeping with previous studies, a high prevalence of IVPs was described in most of the included studies, although this differed depending on the practice described. With the majority of participants in the included studies recruited from health care facilities, it has been proposed that health professionals may be well positioned to ascertain whether IVPs are utilised and to promote education and awareness about their possible risk. ${ }^{51-53}$ Some scholars have proposed group delivered interventions for peer support and motivation to facilitate discussion, and possibly cessation, of IVPs may be effective. ${ }^{54,55}$ 
Health education interventions about the potential risk of IVPs have often been implemented in the context of HIV infection, ${ }^{53,56}$ where the importance of using culturally sensitive and acceptable approaches are well-recognised. This approach could be further adapted to include messages about HPV infection and cervical cancer development. Given that IVPs tend to be socially and culturally engrained, sensitivity is required in understanding their motivating and perpetuating factors and the beliefs surrounding their benefits as well as any cervical cancer risk. ${ }^{5,52,56}$ In addition, a clear distinction should be made between evidencebased practices that may involve intravaginal insertion, such as the clinical use of vaginal suppositories for treating infection and contraceptive vaginal rings ${ }^{57,58}$ from the potentially more harmful insertion practices described in this review. This issue has been a source of concern in some study populations, amongst whom beliefs exist that any product applied intravaginally, even if medically indicated, could be harmful. ${ }^{52}$ It will be important to promote clear public health advice on this topic going forwards, particularly with the potential advent of new evidence-based intravaginal devices such as antiretroviral intravaginal rings for HIV pre-exposure prophylaxis which have been undergoing clinical trials. ${ }^{59-61}$

\section{CONCLUSIONS}

The ability to draw firm conclusions regarding an association of IVPs with HPV infection, or the development of cervical cancer, was limited by the current evidence base. Although the possibility of harm was suggested overall, IVPs were not clearly defined in the identified studies and there was limited capacity to assess mediators of the pathway. It may be necessary to increase awareness related to potential risks of IVPs and to conduct these efforts with cultural sensitivity, but this must be substantiated by more robust evidence to ensure that clear and consistent messages are promoted.

\section{ACKNOWLEDGEMENTS}

We thank Marshall Dozier, Academic Support Librarian at the University of Edinburgh for invaluable advice on search strategies; we also thank Liz Grant and Cecile Wabnitz for early discussion of the interface of IVPs and cervical disease.

\section{FUNDING}

This study had no external funding.

\section{AUTHORSHIP CONTRIBUTIONS}

All authors meet authorship criteria. CC and TM conceived the study; TM led the protocol development and literature searching, and initial data extraction and quality assessment, and data synthesis; RH was the second reviewer. All authors contributed to interpretation of findings, and contributed to the writing of the paper. CC is the guarantor.

\section{COMPETING INTERESTS}

The authors completed the Unified Competing Interest form at www.icmje.org/coi_disclosure.pdf (available upon request from the corresponding author), and declare no conflicts of interest.

\section{CORRESPONDENCE TO:}

Tafadziswa T Museba

Usher Institute, University of Edinburgh, Teviot Place, Edinburgh, EH89AG, United Kingdom.

t.t.museba@gmail.com

Submitted: September 14, 2020 GMT, Accepted: November 17, 2020 GMT 


\section{REFERENCES}

1. World Health Organization (WHO). A Multi-Country Study on Gender, Sexuality and Vaginal Practices: Implications for Sexual Health: Policy Brief. World Health Organization; 2012. Accessed May 3, 2019. htt ps://apps.who.int/iris/handle/10665/75182

2. Hilber AM, Hull TH, Preston-Whyte E, et al. A cross cultural study of vaginal practices and sexuality: Implications for sexual health. Soc Sci Med. 2010;70(3):392-400. doi:10.1016/j.socscimed.2009.1 $\underline{0.023}$

3. Zhang J, Thomas AG, Leybovich E. Vaginal douching and adverse health effects: A meta-analysis. Am J Public Health. 1997;87(7):1207-1211. doi:10.210 5/ajph.87.7.1207

4. Hilber AM, Francis SC, Chersich M, et al. Intravaginal Practices, Vaginal Infections and HIV Acquisition: Systematic Review and Meta-Analysis. Horsley T, ed. PLoS ONE. 2010;5(2):e9119. doi:10.137 1/journal.pone.0009119

5. Menard J, Kobetz E, Diem J, Lifleur M, Blanco J, Barton B. The sociocultural context of gynecological health among Haitian immigrant women in Florida: Applying ethnographic methods to public health inquiry. Ethn Health. 2010;15(3):253-267. doi:10.108 $\underline{0 / 13557851003671761}$

6. Brown JE, Brown RC. Traditional Intravaginal Practices and the Heterosexual Transmission of Disease: A Review. Sex Transm Dis. 2000;27(4):183-187. doi:10.1097/00007435-20000400 $\underline{0-00001}$

7. Schwandt M, Morris C, Ferguson A, Ngugi E, Moses S. Anal and dry sex in commercial sex work, and relation to risk for sexually transmitted infections and HIV in Meru, Kenya. Sex Transm Infect. 2006;82(5):392-396. doi:10.1136/sti.2006.019794

8. Buvé A, Jespers V, Crucitti T, Fichorova RN. The vaginal microbiota and susceptibility to HIV. AIDS. 2014;28(16):2333-2344. doi:10.1097/qad.0000000000 $\underline{000432}$

9. Low N, Chersich MF, Schmidlin K, et al. Intravaginal Practices, Bacterial Vaginosis, and HIV Infection in Women: Individual Participant Data Meta-analysis. Mofenson L, ed. PLoS Med. 2011;8(2):e1000416. doi:10.1371/journal.pmed.10004 16
10. Ginsburg O, Bray F, Coleman MP, et al. The global burden of women's cancers: A grand challenge in global health. Lancet. 2017;389(10071):847-860. doi:1 $\underline{0.1016 / \mathrm{s} 0140-6736(16) 31392-7}$

11. Schiffman M, Wentzensen N. From Human Papillomavirus to Cervical Cancer. Obstet Gynecol. 2010;116(1):177-185. doi:10.1097/aog.0b013e3181e46 $\underline{29 f}$

12. IARC Working Group on the Evaluation of Carcinogenic Risks to Humans. Biological agents. Volume 100 B. A review of human carcinogens. IARC Monogr Eval Carcinog Risks Hum. 2012;100(Pt B):1-441. https://www.ncbi.nlm.nih.gov/pubmed/231 $\underline{89750}$

13. Chelimo C, Wouldes TA, Cameron LD, Elwood JM. Risk factors for and prevention of human papillomaviruses (HPV), genital warts and cervical cancer. J Infect. 2013;66(3):207-217. doi:10.1016/j.jin f.2012.10.024

14. Denny LA, Franceschi S, de Sanjosé S, Heard I, Moscicki AB, Palefsky J. Human Papillomavirus, Human Immunodeficiency Virus and Immunosuppression. Vaccine. 2012;30:F168-F174. do i:10.1016/j.vaccine.2012.06.045

15. Myers KO, Ahmed NU. The Role of HIV in the Progression through the Stages of the Human Papillomavirus to Cervical Cancer Pathway. AIDS Rev. 2018;20(2):94-1043. doi:10.24875/aidsrev.m18000021

16. Shamseer L, Moher D, Clarke M, et al. Preferred reporting items for systematic review and metaanalysis protocols (PRISMA-P) 2015: Elaboration and explanation. BMJ. 2015;350:g7647-g7647. doi:10.113 6/bmj.g7647

17. Higgins JP, Deeks JJ. Selecting studies and collecting data. In: Higgins J, Green S, eds. Cochrane Handbook for Systematic Reviews of Interventions Version 5.1.0. The Cochrane Collaboration; 2011.

18. Wells G, Shea B, O'Connell D, et al. The Newcastle-Ottawa Scale (NOS) for assessing the quality of non-randomised studies in meta-analyses. Published online 2012. Accessed May 23, 2019. htt p://www.ohri.ca/programs/clinical epidemiology/oxfo $\underline{\text { rd.asp }}$

19. Downes MJ, Brennan ML, Williams HC, Dean RS. Development of a critical appraisal tool to assess the quality of cross-sectional studies (AXIS). BMJ Open. 2016;6(12):e011458. doi:10.1136/bmjopen-2016-0114 $\underline{58}$ 
20. Popay J, Roberts H, Sowden A, et al. Guidance on the conduct of narrative synthesis in systematic reviews: A product from the ESRC Methods Programme. Published online 2006.

21. Francis SC, Ao TT, Watson-Jones D, et al. P3.117 Intravaginal Practices and HIV Acquisition Among Women at High Risk For Infection in Tanzania and Uganda. Sex Transm Infect. 2013;89(Suppl 1):A184 LP-A184. doi:10.1136/sextrans-2013-05118 $\underline{4.0576}$

22. Gough D. Weight of Evidence: A framework for the appraisal of the quality and relevance of evidence. Res Pap Educ. 2007;22(2):213-228. doi:10.1080/02671520 $\underline{701296189}$

23. Bui TC, Scheurer ME, Pham VT, et al. Intravaginal practices and genital human papillomavirus infection among female sex workers in Cambodia. J Med Virol. 2018;90(11):1765-1774. doi:10.1002/jmv.25268

24. Bui TC, Thai TN, Tran LTH, Shete SS, Ramondetta LM, Basen-Engquist KM. Association between Vaginal Douching and Genital Human Papillomavirus Infection among Women in the United States. J Infect Dis. 2016;214(9):1370-1375. doi:10.1093/infdis/iiw38 $\underline{8}$

25. Sagay AS, Imade GE, Onwuliri V, et al. Genital tract abnormalities among female sex workers who douche with lemon/lime juice in Nigeria. Afr J Reprod Health. 2009;13(1):37-45. https://www.ajrh.info/inde x.php/ajrh/article/view/563

26. Luo L, Xu JJ, Wang GX, Ding GW, Wang N, Wang HB. Vaginal douching and association with sexually transmitted infections among female sex workers in a prefecture of Yunnan Province, China. Int J STD AIDS. 2015;27(7):560-567. doi:10.1177/0956462415589044

27. Vandepitte J, Bukenya J, Weiss HA, et al. HIV and other sexually transmitted infections in a cohort of women involved in high-risk sexual behavior in Kampala, Uganda. Sex Transm Dis. 2011;38(4):316-323. doi:10.1097/olq.0b013e31820995 $\underline{45}$

28. Esber A, Rao N, Norris A, et al. Intravaginal practices and prevalence of sexual and reproductive tract infections among women in rural Malawi. Sex Transm Dis. 2016;43(12):750-755. doi:10.1097/olq.00 00000000000531

29. Houlihan CF, de Sanjosé S, Baisley K, et al. Prevalence of human papillomavirus in adolescent girls before reported sexual debut. J Infect Dis. 2014;210(6):837-845. doi:10.1093/infdis/jiu202
30. Lee H, Lee DH, Song YM, Lee K, Sung J, Ko G. Risk factors associated with human papillomavirus infection status in a Korean cohort. Epidemiol Infect. 2014;142(8):1579-1589. doi:10.1017/s0950268813002 $\underline{549}$

31. Seay JS, Mandigo M, Kish J, Menard J, Marsh S, Kobetz E. Intravaginal practices are associated with greater odds of high-risk HPV infection in Haitian women. Ethn Health. 2017;22(3):257-265. doi:10.108 $\underline{0 / 13557858.2016 .1246423}$

32. Sun CA, Hsiung CA, Lai CH, et al. Epidemiologic correlates of cervical human papillomavirus prevalence in women with abnormal pap smear tests: A Taiwan Cooperative Oncology Group (TCOG) study. J Med Virol. 2005;77(2):273-281. doi:10.1002/jmv.204 $\underline{47}$

33. Tarkowski TA, Koumans EH, Sawyer M, et al. Epidemiology of Human Papillomavirus Infection and Abnormal Cytologic Test Results in an Urban Adolescent Population. J Infect Dis. 2004;189(1):46-50. doi:10.1086/380466

34. Ali-Risasi C, Verdonck K, Padalko E, Vanden Broeck D, Praet M. Prevalence and risk factors for cancer of the uterine cervix among women living in Kinshasa, the Democratic Republic of the Congo: A cross-sectional study. Infect Agents Cancer. 2015;10(1):20. doi:10.1186/s13027-015-0015-Z

35. Mbizvo EM, Msuya SE, Stray-Pedersen B, Chirenje MZ, Hussain A. Cervical dyskaryosis among women with and without HIV: Prevalence and risk factors. Int J STD AIDS. 2005;16(12):789-793. doi:10.1258/095646 205774988046

36. van de Wijgert J, Chirenje ZM, Iliff V, et al. Effect of intravaginal practices on the vaginal and cervical mucosa of Zimbabwean women. J Acquir Immune Defic Syndr. 2000;24(1):62-67. https://journals.lww.com/jai ds/Abstract/2000/05010/Effect of Intravaginal_Practi ces on the Vaginal.9.aspx

37. Chu TY, Hsiung CA, Chen CA, et al. Post-coital vaginal douching is risky for non-regression of lowgrade squamous intraepithelial lesion of the cervix. Gynecol Oncol. 2011;120(3):449-453. doi:10.1016/j.ygy no.2010.11.006

38. Moscicki AB, Ma Y, Farhat S, et al. Redetection of cervical human papillomavirus type 16 (HPV16) in women with a history of HPV16. J Infect Dis. 2013;208(3):403-412. doi:10.1093/infdis/jit175

39. Ebrahim S, Mndende XK, Kharsany ABM, et al. High burden of human papillomavirus (HPV) infection among young women in KwaZulu-Natal, South Africa. Meyers C, ed. PLoS ONE. 2016;11(1):e0146603. doi:10.1371/journal.pone.0146 $\underline{603}$ 
40. Shaw E, Ramanakumar AV, El-Zein M, et al. Reproductive and genital health and risk of cervical human papillomavirus infection: Results from the Ludwig-McGill cohort study. BMC Infect Dis. 2016;16(1):116. doi:10.1186/s12879-016-1446-x

41. Gardner JW, Schuman KL, Slattery ML, Sanborn JS, Abbott TM, Overall JC Jr. Is vaginal douching related to cervical carcinoma? Am J Epidemiol. 1991;133(4):368-375. doi:10.1093/oxfordjournals.aj e.a115890

42. Bayo S, Bosch FX, de Sanjosé S, et al. Risk factors of invasive cervical cancer in Mali [Facteurs de risque du cancer invasif du col de l'utérus au Mali]. Int $J$ Epidemiol. 2002;31(1):202-209. doi:10.1093/ije/31.1.2 $\underline{02}$

43. Hull T, Hilber AM, Chersich MF, et al. Prevalence, Motivations, and Adverse Effects of Vaginal Practices in Africa and Asia: Findings from a Multicountry Household Survey. J Women's Heal. 2011;20(7):1097-1109. doi:10.1089/jwh.2010.2281

44. Francis SC, Baisley K, Lees SS, et al. Vaginal practices among women at high risk of HIV infection in Uganda and Tanzania: Recorded behaviour from a daily pictorial diary. Thorne C, ed. PLOS ONE. 2013;8(3):e59085. doi:10.1371/journal.pone.0059085

45. Chisembele M, Rodriguez VJ, Brown MR, Jones DL, Alcaide ML. Intravaginal practices among young HIV-infected women in Lusaka, Zambia. Int J STD AIDS. 2018;29(2):164-171. doi:10.1177/095646241772 1438

46. Booth A, Mshelia S, Analo CV, Nyakang’o SB. Qualitative evidence syntheses: Assessing the relative contributions of multi - context and single - context reviews. J Adv Nurs. 2019;75(12):3812-3822. doi:10.11 $\underline{11 / j a n .14186}$

47. Bennett C, Kuhn AE, Haverkos HW. Human papillomavirus and tar hypothesis for squamous cell cervical cancer. J Biosci. 2010;35(3):331-337. doi:10.10 07/s12038-010-0038-y

48. Martino JL, Vermund SH. Vaginal douching: evidence for risks or benefits to women's health. Epidemiol Rev. 2002;24(2):109-124. doi:10.1093/epire $\mathrm{v} / \mathrm{mxf004}$

49. Gillet E, Meys JFA, Verstraelen H, et al. Bacterial vaginosis is associated with uterine cervical human papillomavirus infection: A meta-analysis. BMC Infect Dis. 2011;11(1):10. doi:10.1186/1471-2334-11-10
50. Gillet E, Meys JFA, Verstraelen H, et al. Association between Bacterial Vaginosis and Cervical Intraepithelial Neoplasia: Systematic Review and Meta-Analysis. Atashili J, ed. PLoS ONE. 2012;7(10):e45201. doi:10.1371/journal.pone.004520 1

51. Martino JL, Youngpairoj S, Vermund SH. Vaginal Douching: Personal Practices and Public Policies. J Women's Heal. 2004;13(9):1048-1065. doi:10.1089/jw $\underline{\text { h.2004.13.1048 }}$

52. McFarland DM. Beliefs about the causes of cervical cancer in Botswana: Implications for nursing. Int Nurs Rev. 2009;56(4):426-432. doi:10.1111/j.146 6-7657.2009.00742.x

53. Alcaide ML, Rodriguez VJ, Fischl MA, Jones DL, Weiss SM. Addressing intravaginal practices in women with HIV and at-risk for HIV infection, a mixed methods pilot study. Int J Womens Health 2017;9:123-132. doi:10.2147/ijwh.s125883

54. Masese L, McClelland RS, Gitau R, et al. A pilot study of the feasibility of a vaginal washing cessation intervention among Kenyan female sex workers. Sex Transm Infect. 2013;89(3):217-222. doi:10.1136/sextra ns-2012-050564

55. Esber A, Moyo P, Munjoma M, et al. Cessation of intravaginal practices to prevent bacterial vaginosis: A pilot intervention in Zimbabwean women. Sex Transm Infect. 2015;91(3):183-188. doi:10.1136/sextra ns-2014-051764

56. Alcaide ML, Chisembele M, Malupande E, et al. A bio-behavioral intervention to decrease intravaginal practices and bacterial vaginosis among HIV infected Zambian women, a randomized pilot study. BMC Infect Dis. 2017;17(1):338. doi:10.1186/s12879-017-24 $\underline{36-3}$

57. Brache V, Payán LJ, Faundes A. Current status of contraceptive vaginal rings. Contraception. 2013;87(3):264-272. doi:10.1016/i.contraception.201 $\underline{2.08 .037}$

58. Monteiro I, Guazzelli CF, Bahamondes L. Advances in contraceptive vaginal rings: What does the future hold? Expert Opin Pharmacother. 2018;19(15):1685-1691. doi:10.1080/14656566.2018.1 $\underline{519549}$

59. Vincent KL, Moss JA, Marzinke MA, et al. Safety and pharmacokinetics of single, dual, and triple antiretroviral drug formulations delivered by podintravaginal rings designed for HIV-1 prevention: A Phase I trial. Bekker LG, ed. PLoS Med. 2018;15(9):e1002655. doi:10.1371/journal.pmed.1002 $\underline{655}$ 
60. Thurman AR, Schwartz JL, Brache V, et al. Randomized, placebo controlled phase I trial of safety, pharmacokinetics, pharmacodynamics and acceptability of tenofovir and tenofovir plus levonorgestrel vaginal rings in women. Winston A, ed. PLoS ONE. 2018;13(6):e0199778. doi:10.1371/jour nal.pone. 0199778
61. Palanee-Phillips T, Baeten JM. Topical delivery of long-acting antiretrovirals to prevent HIV acquisition. Curr Opin HIV AIDS. 2020;15(1):42-48. $\underline{\mathrm{d}}$ oi:10.1097/coh.0000000000000598 


\section{SUPPLEMENTARY MATERIALS}

\section{Online Supplementary Document}

Download: https://www.joghr.org/article/21349-are-intravaginal-practices-associated-with-human-papillomavirusand-the-development-of-cervical-cancer-a-systematic-literature-review/attachment/54441.docx 